\title{
DEVELOPMENT AND THE LIFE STORY OF A THAI FARMER LEADER ${ }^{1}$
}

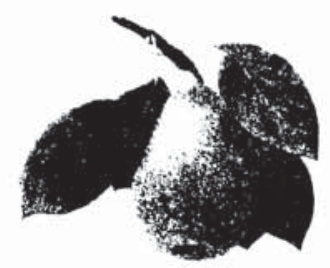

Henry D. Delcore

California State University, Fresno

In the anthropology of development, the contributions of poststructuralist theory have been marred by tendencies toward discursive determinism and an inadequate theorizing of agency. The life history approach is a strategy for probing the cultural politics of development in a way that better addresses the reality of development actors. Development does not just determine what counts as knowledge or truth, but also opens opportunities for individual cultural experiments. Richard Fox's concept of the "cultured life" is here used to explore the various cultural and political entanglements in the life of a northern Thai farmer who has helped pioneer a new form of agricultural development in Thailand. (Development, life history, NGOs, agency, Thailand)

In the 1990s, the anthropology of development saw a move toward poststructuralism and an approach to "development as discourse" (Apffel-Marglin and Marglin 1990; Escobar 1995; Ferguson 1994; Sachs 1992). Yet criticisms of the poststructuralist approach to development noted its overemphasis on the uniformity of development discourse (Grillo 1997; Gupta 1998), a tendency toward "discursive determinism" (Moore 1999), and an inadequate theorization of agency (Moore 1999; Sivaramakrishnan and Agrawal 1998). This article attempts to demonstrate the merits of the life history approach as an avenue of analysis in the anthropology of development that can address some of these problems. It does so by presenting the "cultured life" (Fox 1991) of a northern Thai farmer leader, Berm, who in the 1980s and 1990s became entangled with the politics of development in Thailand and with struggles over development intervention in his home village and district. Berm was confronted with various challenges, including changing livelihood options and the opportunity to become involved in nongovernmental organization (NGO) development efforts. $\mathrm{He}$ creatively engaged the challenges and opportunities in ways consistent with his cultural background, gender, class position, place in local politics, and personal inclinations. Far from a benighted victim of the discursive straitjacket of development, Berm emerged as an influential local figure who appropriated Thai development for personal and political projects that engaged yet also transcended the discourse and material process of development identified by poststructuralist analysts.

\section{THE ANTHROPOLOGY OF DEVELOPMENT}

The poststructuralist direction in the anthropology of development drew particularly on the work of Foucault. This showed that the analysis of development as a discourse could highlight the processes of knowledge and subject production wrought by institutions and actors in the global economy. In his account of the development "apparatus" in Lesotho in the 1980s, Ferguson (1994) argues that

ETHNOLOGY vol. 43 no. 1, Winter 2004, pp. 33-50.

ETHNOLOGY, c/o Department of Anthropology, The University of Pittsburgh, Pittsburgh PA 15260 USA

Copyright 2004 The University of Pittsburgh. All rights reserved. 
although development interventions most often fail to achieve their stated objectives, they nonetheless have important, if unintended, consequences. In Lesotho, development primarily provided for the expansion of state power under the cover of a technical, depoliticized struggle against poverty (Ferguson 1994:256). Ferguson likens the consequences of development intervention to Foucault's instrument-effects, "effects that are at one and the same time instruments of what 'turns out' to be an exercise of power" (Ferguson 1994:255). Escobar (1995:5), also drawing on Foucault, sees discourse analysis as a concern for "how certain representations become dominant and shape indelibly the ways in which reality is imagined and acted upon." Thus, development as discourse permits some modes of thinking and being while discouraging others. In the process, particular kinds of knowledge about the Third World and their subjects are produced and accepted, reinforcing the First World's material and symbolic domination over the Third.

Discourse analysis has helped question both liberal views of development as a tool in the fight against poverty and Marxist arguments that development is merely an extension of the "logic of Capital." Yet several critics view poststructuralist accounts of development as monolithic, "a single gaze or voice which is all-powerful and beyond influence" (Grillo 1997:20). On the other hand, Gupta (1998:16) argues that some Indian peasants have advocated a populist strategy of development and notes that 'the destabilization of a hegemonic notion of 'development' was surely an important indication of the failure of the functioning of some universal and unitary process." Moore (1999) also denies the existence of a development monolith, and criticizes the "discursive determinism" of some accounts, in which development discourse appears as a juggernaut of knowledge and power, a faceless but potent force that few have been able to significantly subvert. In a similar vein, Sivaramakrishnan and Agrawal (1998:25) note that it is often hard to locate agency in poststructuralist analyses of development; they pointedly wonder, for example, how one can refer to "strategies of power" without identifying the agent(s) deploying the strategies. Instead, they argue for greater appreciation of the way that structures can present even disadvantaged actors with new opportunities. Denying a return to the "starry-eyed vision" of the completely free and rational actor, Sivaramakrishnan and Agrawal (1998:28) assert "the impossibility of structures to constrain actions to a unique singular point, eliminating the range within which agents make choices. To deny that strategies have authors or agents logically leads to an insistence on the tyranny of the social."

Moore's (1999) recently proposed idea of the "crucible of cultural politics" is a comprehensive and compelling direction for building on the contributions of poststructuralist analysis of development while avoiding some of its monolithic and determinist tendencies. Moore proposes to portray people whose cultures, local political struggles, and histories of confrontation with state domination critically shape their responses to and appropriations of development. As an example of his approach, Moore recounts the Kaerezi opposition to a government resettlement project in eastern Zimbabwe in the early 1990s, which was inspired by memories of 
expropriation and resettlement efforts during the colonial past. The Kaerezians played a key role in Zimbabwe's independence struggle, during which redress of land issues was a key concern. Faced with yet another resettlement effort by the postcolonial state, they argued that their independence activities made them deserving of exemption from the proposed resettlement. Yet the Kaerezians were far from antidevelopment; in fact, they demanded the state provide them infrastructural improvements. Thus, while development can appear as a discourse of control, it can also be a "discourse of entitlement" (Moore 1999:673). Like Gupta (1998) and Sivaramakrishnan and Agrawal (1998), Moore sees their claims on the state as an opportunity to assert a populist development agenda, albeit one influenced by their particular historical, political, and cultural conditions. Moore (1999:675) concludes:

The challenge of a critical anthropology remains understanding how development and politics are woven together in particular localities, differently deployed, and given form and substance through cultural practices. . . Far from arriving fully formed, an artifact dispatched by the distant West, the disputed formations of development, in all their malleable guises, are forged through the crucible of cultural politics, reworked through livelihood struggles.

\section{LIFE HISTORY}

The works cited above signal the return of the agent to the anthropology of development. But given the powerful material and discursive forces at work in development situations, how can the role of agency in those situations be accurately represented? Moore's case study approach is one option. Another is the life history, which can highlight the complex presence of development discourses and practices in the lives of people who are engaged in development activities. While life history has a long pedigree in anthropological practice, its welter of approaches with little analytical unity casts doubts on its value (Peacock and Holland 1993). Yet life history remains a valuable tool for addressing some current concerns in the anthropology of development. One way this can be realized is with Fox's (1991) model of the "cultured life," which is designed to illustrate the interaction between individual intention and larger structural processes.

The cultured life model, Fox argues, helps study of the ways individuals originate ideas out of existing cultural meanings and experiment with them, and how those ideas may result in change. The study of a cultured life would put the question of structure and agency squarely at the center of the account while showing how cultural experiments are not anonymous, but are authored by particular individuals, resonate (or fail to resonate) with others, are taken up in group struggles, attacked by the opposition, and so forth (Fox 1991:108).

As Moore (1999) points out, people often have long histories of engagement with development strategies, and they respond to the current post-World War II era of development in the context of their particular cultural meanings and practices, historical experiences, and local political struggles. In light of these factors, the challenge is to elaborate the nature of human agency in relation to development in 
any given circumstance, which is what Fox's "cultured life" can address. I address these key issues through Berm's life story, but I am less interested in the narrative of Berm's life than in his life itself-particularly the potential for his story to serve "as a corrective to more structural versions of the historical process" (Scaglion and Norman 2000:137-38). ${ }^{2}$ This requires introducing some background on Thai NGOs and alternative agriculture, which constitutes their distinctive approach to agricultural development.

\section{NGOS AND ALTERNATIVE AGRICULTURE}

During the 1990s, Thai NGOs emerged as an important institutional base for the expression of dissatisfaction with state-led capitalist development (Amara 1995; Costa 2001; Delcore 2003). Indigenous, small-scale NGOs promoted "participatory" (grassroots) development, with emphasis on local determination of development priorities and sustainable rural development through environmentally sound agricultural and resource management practices. ${ }^{3}$ Small-scale Thai NGOs are broadly populist in their rhetoric and, to some degree, their practices. NGO activists usually see themselves as advocates for those who have been neglected by state policies, or as "catalysts" who help the disadvantaged gain the skills and access to the resources they need to press their interests. Indeed, the Thai NGO development goals and practices are significantly different from those of the state (Delcore 2003). During fieldwork (1996-1998), six small-scale NGOs active in Nan Province and one larger organization called Hak Muang Nan (We Love Nan; hereafter HMN) linked a variety of NGOs and village organizations involved in sustainable development. NGO-led development in Nan had a strong Buddhist component and HMN was led by a socially active ecology monk named Phra Khru Phithak, a fact which figures importantly in Berm's story. ${ }^{4}$ Although Nan's NGOs were involved in a variety of projects, including education, health, and forest conservation, all had their roots in a few organizations founded in the early 1990s to promote alternative agriculture (kaseettakam thaang luak), which has become the basis for much NGO rural development work. Since the 1960s, the Thai state has pursued an intense drive for national development based on the extraction of natural resources, promotion of cash crops for export, and export-oriented industrialization (Bello, Cunningham, and Poh 1998; Dixon 1999; Muscat 1994; Pasuk and Baker 1998). Over the last four decades, the area of land cultivated in Thailand has increased rapidly as farmers have moved into forested areas to expand fields for cash crops. In Nan Province, the cash crop of choice since the 1970s has been feed corn for export. While some farmers have realized higher incomes from cash-crop production, many farmers in formerly forested areas (like Nan) have encountered rapidly degrading forest soils, high input costs, commodity price fluctuations, debt, and the need to migrate to cities for wage labor. During the 1980 s, Thai NGO workers in different parts of the country responded to such problems by developing what came to be known as "alternative agriculture. ${ }^{5}$ In its current usage among NGOs, alternative agriculture refers to a 
set of principles that NGO workers seek to apply to agricultural development, such as environmental sustainability, reliance on production-oriented or "subsistence-first" methods, and crop diversification (Alternative Agriculture Network 1996; Nitasmai 1997; Witoon 1992).

In fact, alternative agriculture in Thailand is an umbrella term that encompasses several distinct models, including agroforestry (wanakaseet), natural agriculture as popularized by Japanese ecologist Masanobu Fukuoka ${ }^{6}$ and integrated agriculture (kaseet phasom phasaan), the model employed by Berm. In Thai NGO circles, integrated agriculture refers to the intensive and diversified cultivation of a limited area of land with environmentally friendly methods and reliance on domestic labor. The goals of the method include decreasing land under cultivation (abandoned fields are ideally allowed to return to forest), use of domestic resources, avoidance of debt, and production of a variety of foods for household consumption with only a secondary emphasis on commercial production. Typical integrated farms in Nan include some combination of rice fields (upland or paddy), vegetables plots, fruit trees, fish ponds (for irrigation and fish raising), and livestock such as chickens, ducks, and cattle. Diversification and interconnection between different activities lie at the heart of the method. For example, diversification provides a constant supply of food for the household as well as marketable crops year round. Interconnection between diverse activities occurs, for example, when cattle graze on unwanted grasses in orchard plots and their manure is collected for use as fertilizer on vegetable plots. Diversification (if properly practiced) can also help alleviate some pest problems associated with monocropping and so decrease the need for pesticides, which benefits both the environment and reduces household expenditures.

Integrated agriculture reflects some of the broad principles of Thai NGO-led development: environmental awareness, emphasis on household self-reliance, a wariness of the market, and the struggle against the perceived atomization of village society caused by commercialization and competitive individualism (Delcore 2003). NGO workers often claimed that successful integrated farmers had to be "prayat, khayan, othon" (thrifty, hard working, and persevering), a phrase that evoked images of dutiful community and family members living materially simple lives.

Few development workers or farmers were dogmatic adherents to the integrated agriculture model. Development workers, while committed to the ideals of integrated farming, compromised with farmers on many aspects of the model, such as chemical use; most farmers argued that completely organic methods were untenable. For their part, most farmers who were involved with NGO agricultural projects were less interested in environmental issues and more concerned with boosting cash incomes in order to pay debts and other expenses; thus, they were usually drawn to the prospect that integrated agriculture might provide both diverse marketable produce and food year round. During 1996-98, Nan Province was the site of three nationally renowned integrated farms, including the one run by Berm and his brother, Jamrat. The owners of these three farms served as village- and district-level leaders of NGOaffiliated farmer groups, and frequently hosted visits from farmers from other parts 
of Nan and Thailand. Leaders like Berm often occupied a middle ground between the NGO workers and the farmers involved in NGO projects; at times they approximated sustainable development ideals, yet they also retained some typical farmer sensibilities. Berm's life story exemplifies this process of creative compromise in the practice of NGO-led development. His life also illustrates the collision of development processes with the exigencies of local histories, politics, and personalities.

\section{BERM'S STORY}

In October 1996, I visited the integrated farm that Berm and his brother, Phra Ajaan Jamrat (a monk), had built in their home village, Huay Saay, in Sanamchai District. Berm then was 30, unmarried, and lived in a small, wood-plank, grassthatched house, about a kilometer from the village temple, where his brother was the abbot. The house then lacked electricity, and bath water had to be pumped in from the village.

Berm was involved in numerous activities in Huay Saay. He was a leader of the temple-based youth group, which sponsored sports, agriculture, conservation, art, and other activities. Berm and Jamrat saw the youth group as a bulwark against youth methamphetamine use, which was then attracting national concern. Among men Berm's age, teetotalers were rare, but in 1997, Berm quit drinking in order to set a good example for the youths under his tutelage. Berm also worked part time as a teacher for the Nonformal Education Department, teaching basic school subjects to local adults.

In spite of his many activities, Berm devoted most of his time to practicing and advocating integrated agriculture. His integrated farm was often presented to visitors as the work of Ajaan Jamrat and the village youth group. Indeed, on my first visit to the farm, it was Jamrat who showed me around, and only after Berm approached us with his characteristic friendly smile were we introduced. Eventually I realized that it was largely Berm's labor that had transformed degraded corn fields into an integrated farm with a nationwide reputation. Berm was a model integrated farmer, and a veteran of NGO-led sustainable development activity in general. Yet just a few years earlier, Berm had been far from Huay Saay, living and working as one of the thousands of young labor migrants in Bangkok.

\section{Leaving Home}

Berm was the youngest of seven children. When he was a child, his family had little paddy land and lived largely by planting upland rice and collecting food and other products from the forest. Berm's older brother, Jamrat, tended cattle for other villagers, who bought him clothes and supplies he needed to stay in school. When Jamrat was twelve, he was ordained at the village temple and continued his education there, eventually becoming its abbot. Berm left school at age eleven to help his parents farm. 
In 1981, when Berm was fifteen, his family took up raising feed corn and beans for the market. They were among the first farmers in Sanamchai District to expand corn production by clearing land and adopting Green Revolution technology. State development policy promoted the shift to cash cropping as a way to increase rural incomes and generate foreign exchange from agricultural exports. But Sanamchai is largely hilly and paddy land is extremely limited. Until the 1970s, Berm's parents, like most farmers there, were caught in a system of marginal subsistence production on upland fields. The local farmers were anxious to find ways to boost their cash incomes and improve their material quality of life. Feed corn production, under state and private promotion, seemed like a good opportunity.

When Berm's parents retired, they divided their land among their children. One piece of land to which Berm inherited use rights was near the Huay Saay temple, where the integrated farm now stands. After his parents retired, Berm continued with the same crops for a few years, but by that time the soil had become dry and hard. Like many other farmers who planted corn on Nan's slopes in hopes of getting rich, Berm was forced to increase the amounts of chemical herbicides and fertilizers needed for a good yield, and he went into debt. In 1988, at age 22, he left for Bangkok. He explained:

It was the social trend at that time. Everyone was going to Bangkok then. And I was in debt from planting corn. And I saw others coming back [from Bangkok] with nice clothes and money, and I wanted to have the same. I wanted to see the movie stars, the pop singers, the famous boxers. It was all in Bangkok. And when I was there, I did everything! Soccer matches, boxing at Lumpini Park, everything. Back then, I consumed. When I came back for visits, I didn't want to [help my family] farm. I came home all dressed in nice clothes. My skin was very light then, and when I came home and walked in the fields, I carried an umbrella?

Berm had been caught up in the transformation of the Thai countryside that accompanied the Thai economic boom of the 1980s. Throughout that decade, wages in the factories, construction sites, and service establishments of Bangkok and other cities consistently offered better incomes than farming. Berm and many of his fellow villagers became part of the rural out-migration trend. In the era of mass communication and heightened commodity consumption by the new Thai middle class, the lure of the city has also been bolstered by the romance of modernity (Mills 1999), symbolized for Berm by the nationally televised boxing matches at Lumpini Park, and the pop stars and actors that inform Thai popular culture. Berm's statement that "it was all in Bangkok" succinctly expresses the pull that Thailand's primary city has on young people from the countryside.

Life stage was another influence. In a long-standing pattern, many young Thai men search for experience and excitement outside their home communities before marrying and settling down (Kirsch 1966:375-76). In the past, youthful male wandering found expression in varied ways, including itinerant trading, ordination at a distant temple, service in the military, and labor migration; today, labor migration is the dominant part of this pattern in most of rural Thailand. Berm was 
at the age when Thai men felt the urge to wander just when corn production in Sanamchai was faltering and work in Bangkok emerged as an option.

Berm spent about four years in Bangkok, working at everything from construction to store salesperson. While he was gone, Jamrat got involved with an NGO that was founded in Sanamchai in 1990. Having made contacts with HMN, Jamrat was soon a follower of the Phra Khru Phithak's ecology monk. He started experimenting with integrated agriculture on the land near the temple, with labor provided by the village youth group members. (Thai Buddhist monks are prohibited from doing manual labor.) Later, Jamrat wrote to Berm, and even visited him in Bangkok several times, to ask him to come home and help. Berm refused, for he had become well established in Bangkok, working as a store salesperson, and had achieved a reputation in Huay Saay as someone who could help new or out-of-work migrants find a job.

I didn't want to [come home]. In Bangkok, I didn't have to be exposed to the sun and the dust and there were a lot of pretty women there. And I didn't have to do heavy work in Bangkok, either. I mostly worked in stores. I was the one who inspected the work of others, the one who would go and talk to the boss about this or that. I'm a good talker [smiling]. . . . I didn't want to come back. I was having too much fun. I was lost in the lights of the city. . . .

Yet two years later, in 1992, Berm did return to Huay Saay:

I visited here once and saw the work they had done on the farm and I wanted to help. I was surprised at their progress. And I realized I couldn't live in Bangkok my whole life. . . . When I was in Bangkok, I was a subordinate the whole time. I wondered what would happen when I got older, turned 50. "They're liable to turn me out," I thought. "And if I go back home, I should go back when I'm still young and start building something there." Also, I was thinking about helping develop my home village (phatthanaa baan), helping the community. ... I had gone everywhere and seen everything already, and I saw that it was nothing special. But if I went back and helped build up the community, that would be good. Also, while in Bangkok, I had been reading books about successful people. I saw that they had to fail before reaching success. I saw that I myself had failed. I failed at farming corn. I went to Bangkok but failed to have any money left to send home. . . . Also, around the time I came back, I had been going to study the dharma at Wat Chonprathaan. I went every sabbath to hear the monks' sermons. I knew that our lives are uncertain. ... Wat Chonprathaan played a role in my coming back. I was reading books and other things, about development monks (phra nak phatthanaa) and the People for the Social Good (Khon Dii Sri Sangkhom) in the newspaper, too. I saw people who didn't have any opportunities in life, yet they had accomplished all kinds of things. . . .

Several concerns influenced Berm's decision to return home. He began to look beyond the search for adventure, and saw the underlying instability of life in Bangkok for someone of his status and education. He would not be able to live there comfortably forever. At the same time, he knew that it would take hard work and time to build a secure livelihood in the countryside. Also, his brother appealed to him directly to come home and help on the farm. Berm said that he felt sorry for Jamrat, working virtually alone, with only children to help him. In short, Berm entered a new stage in his life, in which the demands of kin, community, and a secure future for himself encouraged a different way of living. 
An important aspect of the social context that contributed to Berm's return was the growing legitimacy of popular participation in development efforts. When stateled development got underway in the 1960s, government representatives were seen as the exclusive agents of development, bringing civilization and progress to a backward rural populace (Vandergeest 1996). While Berm reports that he felt that he could play a role in developing Huay Saay, it is hard to know how much of his recollection has been influenced by his later activities. Sustainable and grassroots development discourse was increasingly in the public eye in the early 1990s and may have influenced Berm's decision to return home. For example, after 1990, Berm's brother joined the NGO network in Nan just as it was getting started, and he became a conduit for the alternative development ideas circulating in NGO and ecology monk circles. Also, by the early 1990 s, socially active monks were receiving regular media attention for their efforts. For example, the People for the Social Good Award was given annually by a Bangkok-based NGO to someone who contributed to the "good of society." The award, which gets media coverage, often goes to people outside the state structure who work in development.

Finally, Berm started visiting Wat Chonprathaan, a temple operated by followers of Buddhadasa Bhikkhu, a monk widely revered in NGO circles and often seen as a kind of theological godfather for socially engaged Buddhists in Thailand (Jackson 1988; Swearer 1997). There, Berm received further exposure to socially conscious people and alternative ideas about development, along with related teachings from the Buddhist dharma. Bored and dissatisfied with the apparent pointlessness of his life in Bangkok, exposed to the dharma and the work of socially active monks, and urged on by his own NGO-connected brother, Berm decided to go back to the farm and help his home village. Thai NGOs, with their stated adherence to the participatory approach, had at that point gone some way toward pressing the argument that there is more than one way to develop, and that development is something toward which a broad range of people-not just state officials-could and should work.

\section{A Change in Lifestyle}

Shortly after his return, Berm set about clearing the weeds and small trees that covered much of the land near the temple. Berm said that in those early days, the work was so strenuous that he often felt like giving up. At other times he saw the fruits of his labor clearly, such as when a local variety of chili pepper he planted yielded a great harvest. Local NGOs were also sending him on study tours to successful integrated farms. There Berm saw elderly farmers having success with the method and figured that as a young man, he should be able to do as well, if not better. He took to the challenge with enthusiasm:

Whenever I left the farm for some reason, I felt I had to come back with something to plant. I would always come back with a tree or a plant of some kind. People laughed at me because whenever I visited someone's house, I didn't go straight into the house, but instead I went to their garden to see what plants they had, and I'd ask for something [to uproot and plant back home]. . . . 
After about a year, the farm had a functioning mango orchard, vegetable plots, and dry rice fields. NGOs in Nan and other provinces started bringing farmers to visit Jamrat and Berm. Eventually, as the farm progressed, news crews, reporters, and state officials also became frequent visitors. In particular, Berm recalled the day renowned Thai social critic and NGO sympathizer, Dr. Prawate Wase, visited the farm: "There were 50 or 60 people here. I was dressed in shorts and an old jacket I used to work in. Waen [an NGO activist] was here, and she commented, 'Why did you dress so poorly today ?' . . . [But] I felt that if I dressed up, it wouldn't fit with natural farming."

Berm had come a long way from the visiting migrant who walked with an umbrella in the fields. Indeed, other aspects of his life, such as the grass-thatched house without electricity or running water, revealed at least a temporary satisfaction with material simplicity that few other farmers tolerated. (Huay Saay and surrounding villages were in the midst of a building boom, as labor migrants sent money home for new concrete houses and upgrading renovations.) Asked to comment on his radical change of attitude to eat, dress, and live simply, Berm said, "I was reading [Jamrat's] books about natural agriculture (kaseet baep thammachaat) [and] I felt ready to change." He cited cases he read of people who had failed at commercial agriculture, but then came back and were able to make a living by adopting integrated agriculture. ${ }^{8}$

\section{Berm's Understanding of Integrated Agriculture}

As a result of his continued exposure to NGO development work and to other successful integrated farmers, Berm came to his own understanding of integrated agriculture. His integrated agriculture involved planting and raising diverse crops and livestock, and having the different activities connected. He explained as an example that he planted vegetables for household consumption together with fruit trees so that the trees got water when he watered the vegetables. Berm maintained that emphasis should be on subsistence production, as market production would lead to failure because it would create a pressure to monocrop and thus exposure to market fluctuations. For example, concentration on pig-raising for sale would bring disaster if the price of pork fell. But if one emphasized "eating first and selling what is left over" (kin kon lua khaay, a common refrain in NGO circles), one was ensured a use for everything on the farm and would not be vulnerable to market swings. In a break with other farmers working with the NGOs, Berm used no agricultural chemicals. If the farm was truly integrated, he said, pests would have a hard time finding their targets. There were also natural methods available, such as planting vegetables together with marigolds, which repel some harmful insects. Berm felt that chemicalfree farming was related directly to a concern for the environment; he maintained that his soil was healthy, water run-off from the farm was free of pollutants, and all kinds of animals could live there, including beneficial insects. Berm went on to say that integrated agriculture was also connected to forest conservation. He pointed out the 
forest area that he and Jamrat conserved on the hilltop above the farm. "Agriculture needs water," he said, so one had to conserve the forest, too.

Though Berm was wary of the market, he was not dogmatic about avoiding it; indeed, he sent several products from the farm to local markets. During 1997, Berm was courting several eligible young women, saying that he would like to marry a market woman: "I think they're skilled. Even though they have to buy produce from someone else to sell, they still manage to make hundreds of baht every day. If I married a market woman, and she was able to sell the produce from this farm, then we'd really be able to make some money."

\section{Berm as Development Practitioner and Thinker}

By the mid-1990s, Berm was a successful integrated farmer and a firm believer in the method, though he was yet to be an active participant in attempts to spread the model to others. However, a major goal of NGO development efforts is to cultivate village leaders with the ability and confidence to stand up to state and private interests when necessary. Berm, as a young, bright, well-spoken, and successful farmer, quickly came to play this role. From 1993 to 1997, he took advantage of opportunities offered by his NGO friends to transform himself into an active advocate for integrated agriculture. Working together with Jamrat, he served as intermediary between local NGOs and farmers in Huay Saay. In June 1997, he became the leader of the Sanamchai District Sustainable Agriculture Group (part of the HMN network), which included a few dozen farmers from eight villages in the district. In addition to bringing prospective integrated farmers to visit Jamrat and Berm, NGOs began asking Berm to go to national seminars and meetings, usually NGO-sponsored events designed to put farmers from different parts of the country in touch with each other to exchange ideas and experiences.

Berm's work with NGOs also led to an involvement with state development efforts. In 1995, Berm became part of King Rama IX's Pilot Project for Integrated Agriculture, making him one of the first farmers in Sanamchai to benefit from the state's growing interest in sustainable development. In addition to NGO assistance, state aid began to flow to the farm; in 1995, the Sanamchai District agriculture office dug a fish pond there. Soon after, the Provincial Agriculture Office conducted a survey in search of model integrated farms; Berm and four other farmers from Nan were selected, and they traveled to Dusit Palace in Bangkok to receive an award from Princess Sirindhorn, King Rama IX's oldest daughter. For a farmer of modest means, the honor of receiving an award at the palace was enormous. Another experience, which Berm often cited with pride, was his participation in the public input process for the Eighth National Economic and Social Development Plan (for 1997-2001, commonly referred to as "Plan Eight"). Throughout 1995, Thai NGOs lobbied the government to formulate Plan Eight with input from a broad social spectrum. NGOs and the government eventually co-operated in staging discussions and forums about Plan Eight throughout the country in 1996. Berm, through his connection with NGOs 
in Nan, represented his village and district at the regional level and served as a representative from Nan at the national planning meetings. Some provinces sent their governors to the meetings, but, Berm proudly pointed out, "I'm a farmer, and I represented Nan."

Berm's experiences with the Plan Eight process illustrates the NGO strategy of giving village leaders experience and confidence in the face of authority. On one occasion, Berm attended a Plan Eight forum in Bangkok, where state officials and local representatives gathered in a large convention hall. Berm was impressed that those who wanted to go to the microphone to present their views had to wait in line, including high-ranking state officials. There was a quota for villager representation, and two villagers spoke for every one state official. Such procedural points made a strong impression on Berm, and carried over to other aspects of interaction at the meetings. He laughed while recounting the following story. "One day, a [state official] came in late and sat in front of all the villagers. We told him, 'If you come in early, you sit in front. But if you come in later, you sit in back, if it's really going to be like a democracy.' So he got up and went to the back."

Due to government recognition of his efforts, Berm also became involved in state agricultural development planning in Nan. In 1996, he was appointed as a farmer representative to the Provincial Agriculture Committee, a body composed of official, private sector, and public representatives to advise the Provincial Agriculture Office. With the opportunities for leadership that NGO affiliation gave him, Berm proved an enthusiastic and gifted advocate for integrated agriculture. A confident speaker at both NGO and official events, he earned the respect of most farmers in Sanamchai who were interested in integrated agriculture. These experiences culminated in one of Berm's most important accomplishments: in March 1997, he won election as one of two Huay Saay Village representatives to the Tambon Administrative Organization (TAO), a new organ of local (subdistrict level) government that was part of state administrative decentralization efforts. Berm saw TAO membership as a great opportunity for development in Huay Saay. "It's like a dream come true," he said, explaining that in the past, only the village headman and his advisors could propose development projects to the TAO's predecessor, the Tambon Council. In the new TAO, village representatives could also advance proposals, and Berm planned to use his position to advocate for sustainable development initiatives. Berm was also aware of jealousy among some fellow villagers, who wondered why so much help and attention were channeled toward him. As TAO representative, he said, he could pull different programs into the village for the benefit of all farmers.

Berm once described a plan he had to hold a seminar in the subdistrict to help local leaders learn about development planning. "People here still don't know what development (kaan phatthanaa) is or what it means." He illustrated what he meant:

Suppose the roof on that chicken coop down there is falling apart, and we go fix it. That's development. There are many aspects of development. You can have development of the mind and spirit (jitjay), also. For example, when I was in Bangkok, I liked to gamble, to go to boxing matches and gamble, and all 
that. But then I developed myself to a more acceptable point. . . . Or with agriculture, we had corn before, but now we've developed into integrated agriculture.

In his reference to the development of mind and spirit, Berm was entering into the society-wide contest in Thailand over the meaning of "development," clearly laying claim to the Buddhist-influenced aspects of NGO development philosophy and its critique of the materialistic orientation of state policy. He also argued that development, and integrated agriculture in particular, was more than just one's livelihood. Integrated agriculture involved both economic value (secure livelihood, low expenses) and an awareness of environmental concerns. Further, development to Berm was highly personal, linked to his own transformation from a high-living migrant in Bangkok to a responsible and respected member of his home community. To some extent, then, Berm saw his own life story as subsumed by the idea of development, which provided an idiom for self-understanding. Thus, Berm defined development not just in terms of selected material and spiritual elements, but as an entire way of life as well.

\section{Development and Local Politics}

Resource extraction in the name of development has fueled rural struggles over rights to water, land, and forests, sometimes heightening political divisions in rural communities as factions jockey to protect their interests and values. Huay Saay was such a village. Thus, Berm's success at integrated farming and his election to the TAO were more than simply victories for NGO-led development. As Berm came into his own as an NGO-affiliated farmer leader, he did not shed his interests as an actor embedded in his political, social, and cultural context. In other words, Berm was vying for power as well.

There were two factions in Huay Saay Village: one led by Jamrat and Berm, the other by a wealthy villager named Luan. Competition between the two groups dates to when Jamrat first became involved in development and conservation issues. Since at least the mid-1980s, Luan and his group were involved in illegal logging in the forests surrounding the village. In the early 1990s, Jamrat began advocating forest conservation as part of sustainable development, and soon met resistance from Luan's group. Eventually, however, forest conservation became more accepted in the area and official sanctions against illegal logging grew tougher. Jamrat also made alliances with HMN and other NGOs, which enabled him to bring development activities and resources into the village. Berm's success at allying himself with state development initiatives also bolstered their position. As a result, Jamrat and Berm managed to balance the power between Luan's group and their own, and each drew on different groups of villagers for support. Jamrat controlled the temple, and used it as a base for his community development activities, while Luan's group controlled the village headman and his assistants.

The tension between the temple and headman factions came to a head in 1996 in a dispute over a Tambon Council-funded paved road leading into Huay Saay. Berm 
accused the contractors of using substandard sand and gravel from a local river for the road project. Together with some fellow villagers, Berm called for action from the subdistrict head and Luan, who was then Huay Saay headman. Luan in turn accused Berm of stirring up trouble. Eventually, however, the contractors (who happened to be Berm and Jamrat's affines) agreed to using the more costly sand and gravel from a neighboring district. Berm persisted in his attack on Luan, however, calling for his resignation. As he explained:

I said [Luan] was a bad headman, he brought inferior materials into the village, didn't keep the villagers informed, and many other things. Luan left office, but his assistant was elected in his place, and he's no good either. He can't pull any programs into the village, and the villagers are complaining about that.

In a patronizing mood, Berm went on to claim that his own election to the TAO probably saved Luan's faction from losing the headmanship because he would use his connections to bring more development projects into Huay Saay, thus decreasing pressure on the headman.

Berm's election to the TAO was a victory for the temple faction in Huay Saay. Jamrat and Berm had gained a further foothold in the official structure of power in the area, and a way to counter the power of Luan's faction despite their control of the headmanship. As Berm envisioned it, Luan and his group would have to rely on Berm's development savvy to retain legitimacy in the eyes of the villagers. Nan's NGOs had helped Berm develop into an effective advocate for sustainable development; Berm in turn carried his skills and experiences home to Huay Saay and applied them to the factional conflict in the village.

\section{Farmer or Development Worker}

In many ways, Berm's daily life remained closely linked to the demands of his farm. Several times he showed concern for the animals he raised. His care for the chickens, geese, pigs, and other animals in the garden revealed much about Berm's personal inclinations. After Jamrat and Berm obtained 100 egg chickens in 1997, Berm had to collect the eggs from the coop twice a day and closely monitor the feed and water. While away from the farm, Berm often mentioned his concern about whether the chickens and other animals were being tended to properly. This care was also part of the economic logic of farming. Jamrat later explained that part of the reason they were having success in egg production was the quiet, peaceful environment they promoted. Calm, well-tended chickens were good egg-laying chickens.

By 1998, Berm was increasingly taking on NGO workers' roles, working with Jamrat to write funding proposals for development projects being run out of the village temple, and co-ordinating the proceedings of local farmer groups. He was also increasingly busy with his TAO responsibilities. Even his appearance changed. More frequently he was seen neatly dressed, hair combed, and on his way to a meeting. 
In fact, he was ambivalent about his new situation, and complained that he was being pulled in too many different directions.

\section{CONCLUSIONS}

Berm may seem an odd choice for this application of Fox's idea of the cultured life, as following Fox's lead more closely might require the life history of a "higher level" experimenter; a prominent Thai NGO leader, or Buddhadasa Bhikkhu, or perhaps Nan's own Phra Khru Phithak. Berm occupies more of a middle level in the hierarchy of cultural innovation, a link between the theoreticians of the Thai NGO and ecology monk movements and the many lesser farmers who were attracted to alternative agriculture. How, then, did Berm take up and experiment with the material and cultural resources presented to him by both development and by his particular historical, cultural, and political circumstances? Coming from a family of modest subsistence farmers, Berm's early life was caught up in the intersection between state promotion of the Green Revolution and his parents' desires for material improvement. When feed corn production proved disappointing, Berm followed a familiar Thai male pattern, leaving home in search of adventure. This took him to the other side of state-led development: the booming economy of pre-1997 Bangkok, the culturally attractive ground zero of Thai modernity. His return home was conditioned by life-stage concerns and by the opportunities of NGO-led, Buddhistinfluenced sustainable development efforts. From there he moved rapidly into a new lifestyle of hard work and material simplicity, and then rose through the ranks of NGO-affiliated farmers to become an advocate for sustainable development. At each turn, Berm took advantage of opportunities for his own ends.

To Berm, sustainable development in the guise of integrated agriculture became an integral part of his identity and way of life, though heavily conditioned by specific local and personal meanings and interests. He appropriated the integrated agriculture model without dogmatic adherence to its ideals, he was a model subsistence-oriented farmer who also wanted to marry a market woman, and he exploited the experiences and connections he gained through NGO involvement to enter into village and subdistrict politics. Given his circumstances (kin, class, community, and culture, competing development models and agricultural practices, political factions, and NGO connections), Berm must rank as one of a small number of Thais who have recombined the social and cultural raw materials with which they were presented to pioneer new development directions for their society. Structure (including development) provides both opportunities and constraints, but it takes people like Berm, with particular personal and social positions, to turn openings into change. It is difficult to determine how Berm's experiments and activities affected the symbolic and material structures of development in his home village and beyond.

It is significant, however, that farmers in Sanamchai had among them a fellow farmer who not only preached development to include chicken coops, mind and spirit, and environmental well-being, but also at least for a time actually followed a 
lifestyle consistent with his words. Just as Berm earlier drew strength from visiting successful integrated farms, it seems likely that future alternative agriculture success stories will turn out to have their roots in a visit to Berm's farm.

On a broader level, the overwhelming majority of Thais remain committed to development for their society, testimony to the power of development as an idiom for organizing a wide range of social and cultural ideas and practices. At the same time, sustainable development, alternative agriculture, and other NGO development discourse keywords have increasingly entered the Thai public consciousness over recent decades, forcing even the Thai state to take notice. Thai-style sustainable development does depart in significant ways from the development strategy of the Thai state. State-led rural development is based on the idea of a superior urban elite bringing progress to a backward peasantry through technology, industry, markets, and global integration. By contrast, Thai NGO-led development has a more populist face, and calls for the reorientation of politics and economics to local and, in some cases, non-material ends. Berm's claim that farming success hinges on planting crops for subsistence, and with an eye on environmental consequences, is a far cry from the commercialization of rural life that has been the preoccupation of most postWorld War II rural development efforts. Thus, whatever the structural consequences of Berm's life, his story clearly reveals that development is neither monolithic, nor is any particular version of development discourse determinative of individual or collective outcomes in any given case.

Some of Berm's neighbors persisted in planting feed corn and other extensive high-input cash crops, while others tried to follow Berm's lead, joining with his Sanamchai District Sustainable Agriculture Group. Yet as noted above, Berm's fellow alternative farmers were just as wary of NGO development dogma as they were skeptical of the state's promises of riches from cash crops. Indeed, Berm himself was far from a mere tool of NGO development discourse. Thai NGOs claimed to be interested in empowerment: developing village leaders who could stand up and voice the interests of small-scale farmers. Berm, in his facility at taking up the role of farmer leader, might be seen as a success story in an NGO allegory of grassroots development and democracy. But Berm was not merely a modest villager empowered by NGOs. He constructed a livelihood, a lifestyle, and an identity inextricable from his understanding of development. He, too, played the power game, as a local political leader who manipulated NGO and state bureaucracies to provide him and his followers with more resources and opportunities. Like all aspects of development, then, the development discourse and practices promoted by Thai NGOs were not immune to the messy contingencies of lives as they are actually lived.

NOTES

1. The research for this article was conducted with support from a Fulbright-Hays Doctoral Dissertation Research Abroad Fellowship (United States Department of Education), a Wenner-Gren Foundation Small Grant, and funding from California State University, Fresno.

2. Berm's life story presented here draws on interviews and participant observation conducted with him and those close to him. 
3. Indigenous NGOs are those organized and staffed primarily by Thais. Small-scale organizations tend to lack formal affiliations with transnational NGOs (though their funding has traditionally come from both private and governmental donors overseas), and employ between two and five staffers.

4. The first monks to be involved in development work in the 1970s were called "development monks" (phra nak phatthanaa), but by the 1990s the term "ecology monk" (phra nak anurak) had gained ground, reflecting the environmental concerns of many socially active monks. On development and environmental activism by Thai Buddhist monks, see Darlington (1990, 2000), Somboon (1988), Taylor (1993, 1997); on Phra Khru Phithak in particular, see Darlington $(1997,1998)$ and Delcore (2000).

5. Some Thai development workers drew on experiences with international NGOs and Western development volunteers for their ideas, and "kaseettakam thaang luak" is likely a Thai translation of the English term "alternative agriculture." Support for "sustainable agriculture" has been included in principle in the state's seventh (1992-96) and eighth (1997-2001) national development plans. But official "sustainable agriculture" is largely consistent with the state's emphasis on commercial production using Green Revolution technology. Different NGOs and farmer groups used both "alternative agriculture" and "sustainable agriculture" to describe what they do.

6. In 1987, Fukuoka's One Straw Revolution was translated into Thai and was widely read in the NGO community.

7. Labor migrants say that light skin, which Thais value as attractive, is a benefit of working in Bangkok if one found work indoors.

8. His readings included publications of the national Alternative Agriculture Network (from Jamrat's extensive personal library), which have made alternative agriculture ideas more accessible outside NGO circles (Witoon 1992). Such publications represented another way in which sustainable development ideas gained more exposure in Thai society.

\section{BIBLIOGRAPHY}

Alternative Agriculture Network. 1996. Botnam: phatthanakaan khong rabop kaseettakam thaang luak nay phaak nua (Introduction: The Development of Alternative Agriculture in Northern Thailand). Phuumpanyaa kaseettakam: prasopkaan jaak laan naa (Agricultural Wisdom: Experiences from Laan Naa), ed. P. Kowakunphanit, pp. 7-15. Bangkok.

Amara P. 1995. Nongovernmental Organizations in Thailand. Emerging Civil Society in the Asia Pacific Community, ed. T. Yamamoto, pp. 245-70. Tokyo.

Apffel-Marglin, F., and S. A. Marglin. 1990. Dominating Knowledge: Development, Culture and Resistance. Oxford.

Bello, W., S. Cunningham, and L. K. Poh. 1998. A Siamese Tragedy: Development and Disintegration in Modern Thailand. London.

Costa, L. R. 2001. Developing Identities: The Production of Gender, Culture and Modernity in a Northern Thai Non-Governmental Organization. Ph.D. dissertation, University of Hawai'i. Manoa.

Darlington, S. M. 1990. Buddhism, Morality and Change: The Local Response to Development in Northern Thailand. Ph.D. dissertation, University of Michigan. Ann Arbor.

1997. Not Only Preaching: The Work of the Ecology Monk Phrakhru Pitak Nantakhun of Thailand. Forest, Trees and People Newsletter 34:17-19.

1998. The Ordination of a Tree: The Buddhist Ecology Movement in Thailand. Ethnology 37(1):1-15.

2000. Rethinking Buddhism and Development: The Emergence of Environmentalist Monks in Thailand. Journal of Buddhist Ethics. http://jbe.gold.ac.uk/7/darlington001.html.

Delcore, H. D. 2000. Localizing Development: Environment, Agriculture, and Memory in Northern Thailand. Ph.D. dissertation, University of Wisconsin. Madison. 
2003. Nongovernmental Organizations and the Work of Memory in Northern Thailand. American Ethnologist 30(1):61-84.

Dixon, C. 1999. The Thai Economy: Uneven Development and Internationalisation. London.

Escobar, A. 1995. Encountering Development: The Making and Unmaking of the Third World. Princeton.

Ferguson, J. 1994 (1990). The Anti-Politics Machine: "Development," Depoliticization, and Bureaucratic Power in Lesotho. Cambridge.

Fox, R. G. 1991. For a Nearly New Culture History. Recapturing Anthropology: Working in the Present, ed. R. G. Fox, pp. 93-113. Santa Fe.

Grillo, R. D. 1997. Discourses of Development: The View from Anthropology. Discourses of Development: Anthropological Perspectives, eds. R. D. Grillo and R. L. Stirrat, pp. 1-33. Oxford.

Gupta, A. 1998. Postcolonial Developments: Agriculture in the Making of Modern India. Durham NC.

Jackson, P. A. 1988. Buddhadasa: A Buddhist Thinker for the Modern World. Bangkok.

Kirsch, A. T. 1966. Development and Mobility among the Phu Thai of Northeast Thailand. Asian Survey 6(7):370-78.

Mills, M. B. 1999. Thai Women in the Global Economy: Consuming Desires, Contested Selves. New Brunswick NJ.

Moore, D. S. 1999. The Crucible of Cultural Politics: Reworking "Development" in Zimbabwe's Eastern Highlands. American Ethnologist 26(3):654-89.

Muscat, R. J. 1994. The Fifth Tiger: A Study of Thai Development Policy. Helsinki.

Nitasmai T. 1997. Sustainable Agriculture in Thailand. Seeing Forests for Trees: Environment and Environmentalism in Thailand, ed. P. Hirsch, pp. 268-86. Chiang Mai.

Pasuk P., and C. Baker. 1998. Thailand's Boom and Bust. Seattle.

Peacock, J. L., and D. C. Holland. 1993. The Narrated Self: Life Stories in Process. Ethnos 21(4):36783.

Sachs, W. (ed.) 1992. The Development Dictionary: A Guide to Knowledge as Power. London.

Scaglion, R., and M. Norman. 2000. Where Resistance Falls Short: Rethinking Agency through Biography. Identity Work: Constructing Pacific Lives, eds. P. J. Stewart and A. Strathern, pp. 121-38. Pittsburgh.

Sivaramakrishnan, K., and A. Agrawal. 1998. Regional Modernities in Stories and Practices of Development. Crossing Borders: Revitalizing Area Studies, Rethinking Development and Environment. New Haven.

Somboon S. 1988. A Buddhist Approach to Development: The Case of "Development Monks" in Thailand. Reflections on Development in Southeast Asia, ed. L. T. Ghee, pp. 26-48. Singapore.

Swearer, D. K. 1997. The Hermeneutics of Buddhist Ecology in Contemporary Thailand: Buddhadasa and Dhammapitaka. Buddhism and Ecology: The Interconnection of Dharma and Deeds, eds. M. E. Tucker and D. R. Williams, pp. 21-44. Cambridge MA.

Taylor, J. L. 1993. Social Activism and Resistance on the Thai Frontier: The Case of Phra Prajak Khuttajitto. Bulletin of Concerned Asian Scholars 25(2):3-16.

1997. Thamma-chaat: Activist Monks and Competing Discourses of Nature and Nation in Northeastern Thailand. Seeing Forests for Trees: Environment and Environmentalism in Thailand, ed. P. Hirsch, pp. 37-52. Chiang Mai.

Vandergeest, P. 1996. Real Villages: National Narratives of Rural Development. Creating the Countryside: The Politics of Rural and Environmental Discourse, eds. E. M. DuPuis and P. Vandergeest, pp. 279-302. Philadelphia.

Witoon L. (ed.) 1992. Kaseetakaam thaang luak: hon thaang rot khong kaseetakam thay (Alternative Agriculture: The Path of Survival for Thai Agriculture). Bangkok. 